NASA Technical Memorandum 89908

AIAA-87-9035

\title{
Performance Characteristics of a Combination Solar Photovoltaic Heat Engine Energy Converter
}

Donald L. Chubb

Lewis Research Center

Cleveland, Ohio

Prepared for the

22nd Intersociety Energy Conversion Engineering Conference cosponsored by the AIAA, ANS, ASME, SAE, IEEE, ACS, and AIChE Philadelphia, Pennsylvania, August 10-14, 1987 
Donald L. Chubb

National Aeronautics and Space Administration

Lewls Research Center

cleveland, Ohto 44135

Abstract

A combination solar photovoltaic heat engine energy converter is proposed. Such a system is sultable for elther terrestlal or space power applications. The comblnation system has a higher efficlency than either the photovoltalc array or the heat engine alone can attain. Advantages in concentrator and radiator area and receiver mass of the photovoltaic heat engine system over a heatc. engine-only system are estimated. A mass and area comparison between the proposed Space Station organic Rankine power system and a combination PV-heat engine system is made. The critical problem for the proposed converter is the necessity for high-temperature photovoltalc array operation. Estimates of the required photovoltalc temperature are presented.

\begin{tabular}{|c|c|}
\hline & Nomenclature \\
\hline$A_{C}$ & concentrator collection area, $\mathrm{m}^{2}$ \\
\hline$A_{h}$ & effective heat transfer area of PV array, $\mathrm{m}^{2}$ \\
\hline APV & active photovoltaic area, $\mathrm{m}^{2}$ \\
\hline$A_{R A D}$ & radiator area, $\mathrm{m}^{2}$ \\
\hline AREC & aperture area of recetver, $\mathrm{m}^{2}$ \\
\hline$A_{5}$ & structural area in PV array, $m^{2}$ \\
\hline $\mathbf{A}_{T}$ & total area of PV array, Apv $+A_{s}, m^{2}$ \\
\hline a & ratio of $A_{h}$ to $A_{T}$ \\
\hline B & electrical storage specific mass, $\mathrm{KG} / \mathrm{KW}$ \\
\hline C & concentrator specific area, $\mathrm{m}^{2} / \mathrm{kw}$ \\
\hline$c_{p}$ & $\begin{array}{l}\text { specific heat of working fluid at PV array, } \\
\mathrm{J} / \mathrm{kg} \mathrm{K}\end{array}$ \\
\hline fpV & fraction of active area in PV array. APV/AT \\
\hline$n$ & $\begin{array}{l}\text { heat transfer coefflctent between PV array } \\
\text { and working fluid. } \mathrm{W} / \mathrm{m}^{2} \mathrm{~K}\end{array}$ \\
\hline k & $\begin{array}{l}\text { heat transfer parameter for PV array } \\
\text { (Eq. }(20)), x\end{array}$ \\
\hline M & mass, kg \\
\hline m & speciftc mass, $\mathrm{kg} / \mathrm{kW}$ \\
\hline $\mathrm{P}$ & power, W \\
\hline DSUN & $\begin{array}{l}\text { solar fiux }\left(1.35 \mathrm{~kW} / \mathrm{m}^{2} \text { at earth orbit }\right) \text {. } \\
\mathrm{kW} / \mathrm{m}^{2}\end{array}$ \\
\hline $\mathrm{R}$ & recelver spectfic mass, $\mathrm{kg} / \mathrm{kW}$ \\
\hline $\mathbf{r}$ & radiator speciftc mass, $\mathrm{kg} / \mathrm{kW}$ \\
\hline T & temperature, $k$ \\
\hline
\end{tabular}

$\Delta T$ temperature rise between working flutd and PV array, $T_{P V}-\mathrm{T}_{8}$

$t_{\text {SH }}$ time system is in shade

$t_{\text {SUN }}$ time system is in sunlight

$\checkmark$ heat transfer parameter for PV array

(EQ. $(C-7)$ ), $1 / K$

a absorptivity of PV array

aBAT specific energy density of electrical energy storage system, $\mathrm{kWh} / \mathrm{kg}$

BREC specific mass of receiver. $\mathrm{kg} / \mathrm{kW}$

$\Gamma_{B A T}$ parameter that compares electrical energy storage efficlency to thermal energy storage efficlency (Eq. (5))

YBAT

parameter that determines effectiveness of electrical energy storage (Eq. (15))

$c$

emissivity

effictency

$\mu$

time parameter (Eq. (6))

$\rho$

reflectivity of PV array

o

Stefan-Boltzmann constant, $5.67 \times 10^{-8} \mathrm{~W} / \mathrm{m}^{2} \mathrm{~K}^{4}$

T

transmittance of PV array

Subscripts

B

working flutd location at entrance to PV array

BAT

electrical energy storage system

c concentrator

EL electrical power output

HE heat engine

in input power

PV PV array

REC recelver

REJ heat leaving PV array to working fluid of system

st stored energy or power

$T \quad$ PVHE system

0 heat-engine-only system 


\section{Superscripts}

PV portion or PVHE system

electrical energy or power supplied to load from PV portion of PVHE system

\section{Introduction}

The proposed energy converter combines a PV array and a heat engine to produce a higher combined power system efficlency than either a PV array or heat englne alone can attain. Improved efficlency is achleved by splitting the solar spectrum. Part is converted by the PV array and the remaining part converted to heat for use in a heat engine. photovoltalc systems that split the solar spectrum in order to obtain better performance have been constered.1-4 Multiple cells with different energy bandgaps are used in these systems. Each cell is designed to have maxtmum response to a different portion of the solar spectrum. Two approaches have been considered. The first approach attempts to construct a multiplebandgap cell as a single structure. The other approach uses separate PV cells and splits the solar spectrum with beam splitters, ${ }^{2}$ prisms, 3 or diffraction gratings. 4 Early studies 3.4 using prisms or diffraction gratings showed no imorovements in performance when all the optical losses wereconsldered. However, the latter study using highly efficlent beam splitters ${ }^{2}$ predicts an efficlency greater than 30 percent for a three cell system.

For the proposed PV-heat engine (PVHE) converter to be successful, the PV array must absorb photons in the energy range that can be efficiently converted to electrical energy. Photons outside this energy range must be elther transmitted or reflected to a recelver which converts the photon energy to thermal energy. The thermal energy is then converted to electrical energy by a heat engine.

Improved efficlency means that a smaller, less massive energy converter can be constructed. As a result, the PVHE converter is applicable to both terrestrial and space applications. Besldes the efficlency, size and mass improvements, the PVHE converter offers another important advantage. since the PVHE converter consists of two independ. ent energy converters there is system redundancy. Should one of these energy converters fall the other converter is avallable to produce a portion of the electrical power requirement. This system redundancy is inherent in the PVHE system.

\section{Description of Solar PV Heat Engine (PVHE) Systems}

There are two possible configurations for the PVHE converter. Both of these conflgurations are shown in $\mathrm{Fig} .1$. In the transmitting system (Fig. I(b)), the PV array absorbs the portion of the spectrum that can be efficlently converted to electrical energy, $P_{E L}^{\prime}$, and transmits the remaining spectrum to the recelver. In the reflecting system (Fig. la) the PV array reflects the unused portion of the spectrum to the recelver. The photon flux incident on the recelver is converted to thermal energy. This energy together with the thermal waste energy of the PV array, $P_{R E J}$, is then used by the heat engine to produce electrical energy. PEL. The waste heat, PRAD, must then be rejected. For a space system the waste heat must be rejected as thermal radiation.

For a space system in Earth orbit storage of energy is necessary during the portion of the orbit that is in sunlight. This energy is then used during the shade portion of the orbit. In Fig. I both electrical and thermal energy storage are indicated. For electrical energy storage a portion. P'st/n'st, of the total PV array power output. PEL. is stored and the remaining portion, $P_{E L}^{\prime \prime}$, is supplied to the load. A portion, $P_{s t} / n_{s}$. of the thermal power output of the recelver during the sun portion of the orbit is stored for use by the heat engine during the shade portion of the orbit.

The efficlency relations for the two systems in Fig. I have simllar forms. Therefore, efficlency, mass, and area improvements compared to a heat engtne only converter will be simllar for each system. 0ifferent design advantages and disadvantages exist between the systems, however. For the transmitting system there are no difficult optical design problems for the PV array. Whereas the reflecting system requires an accurate optical surface on the PV array in order to direct the input light flux to the receiver. It may also be possible to design the PV array in the transmitting system as a lens to focus the input light on the recelver aperture. Thus radiation emission losses of the recelver would be reduced.

The princlpal design difficulty for the PV array of the transmitting system is providing for the removal of the waste heat. If cooling colls are used within the array then the light intercepted by the colls cannot be utllized by the PV array. It would be desirable to locate the cooling colls on the outer edge of the PV array to ellminate the light blockage problem. The reflecting system does not have this problem. The backside of the PV array can be covered with cooling colls without causing any performance loss.

Since the reflecting system is a Cassegrainian design it has structural advantages over the transmitting system. With the concentrator and recelver located next to each other pointing of the system is simpler than for the transmitting system.

A) though there are design advantages and disadvantages for both systems the major problem for either system is the necessity for the PV array to operate at high temperature. In order to make the PVHE concept feasible a high temperature PV cell must be developed. In a later section the temperature requirements for the PV array wlll be discussed.

Three different configurations of the PVHE converter are of interest. First of all, a system without energy storage, second a system with all thermal energy storage, and finally a system with both electrical and thermal energy storage. As shown in Ref. 5 , the all thermal energy storage system has higher effictency than the combination electrical and thermal energy storage system. However, it also requires that the heat engine operate at two power levels. It must produce electrical power. PEL, during sun time and electrical power, $P_{E L}+P_{E L}$, during shade time. This is an added complication that the system that uses both 
electrical and thermal energy storage does not OF POOR QUALITY

have. In that case the heat engine operates at

the same power level. PEL, all the time. In

this study only the combination electrical and

thermal energy storage PVHE system will be

constdered.

\section{Performance Analysts}

In order to determine the performance of the PVHE systems a model for the optical properties of the PV array is required. It is assumed that the PV array is made up of active PV cells separated by structural materlal. One of the purposes of the structural materlals is to provide cooling of the PV cells. It is assumed that the PV cells and the structural materlal can be characterized by uniform total optical properties (transmittance, $T$ absorptivity, $\alpha$, and reflectivity, $\rho)$. Then if the PV array is 11 luminated by a uniform flux, the optical propertles of the array are fust averages of the PV cell and structural material optical propertles. Also, the electrical power output, $P_{E L}^{\prime}$, of the PV array is given in terms of the power from the concentrator reaching the $P V$ array, $P_{C}$, the $P V$ efficlency, nPV, and the fraction of active $P V$ area, $f_{P V}$.

$$
P_{E L}^{\prime}=f_{P V \cap P V} P_{C}
$$

Also, for conservation of energy, the following relation holds for the PV array.

$$
a+\rho+\tau+f \text { PVחPV }=1
$$

Using the described optical properties and electrical efflctency the performance of the PV array can be calculated.

Effictency. Of primary importance for an energy converter is the overall effictency, nT. This efflctency is defined as follows.

$$
n_{T} \equiv \frac{\left(t_{S H}+t_{S U N}\right)\left(P_{E L}+P_{E L}\right)}{t_{S U N} P_{\text {in }}}
$$

The numerator of Eq. (3) is the total electrical energy produced and the denominator is the total input energy. Where $t_{\text {sun }}$ is the time the system is in the sun and $t_{S H}$ is the time the system is in the shade. For a system in earth orbit ${ }^{t} \mathrm{SH}_{+}+t_{\text {sun }}$ is the orbit perlod. In Ref. 5 the derivation of nT for the various PVHE systems is presented. The form of the expression for ${ }_{n} T$ is the same for both the transmitting and reflecting systems. For a transmitting system that uses both electrical and thermal energy storage the overall effictency is the following

$$
\begin{aligned}
& n_{T}=\mu n_{C}\left\{f_{P V} n_{P V}\left(\Gamma_{B A T}-n_{H E}\right)+{ }^{n} H E\right. \\
&\left.x\left[1-\tau\left(1-n_{R E C}\right)-\rho\right]\right\}
\end{aligned}
$$

Appearing in the expression are the concentrator efficlency. ${ }^{C} \mathrm{C}$, the PV efficlency, nPy, the heat engine efflciency, nHE, the recelver efficlency, nREC, the fraction of active PV area. $f P V$, the $P V$ array transmittance, $T$, and reflectivity, $\rho$, and the parameters, $\Gamma_{B A T}$ and $\mu$.

$$
\begin{aligned}
& \Gamma_{B A T} \equiv \frac{1+\frac{t_{S H}}{t_{S U N}{ }^{n} t}}{t_{S H}} \\
& \mu \equiv \frac{t_{S U N}+t_{S U N}}{t_{S A T}{ }^{n} S t} \\
& t_{S U N}+\frac{t_{S H}}{n_{S t}}
\end{aligned}
$$

The important approximations made in obtaining $n_{T}$ are the following.

1. Radiation loss from PV array negliglble compared to radiation loss from recelver.

2. Radiation from receiver impinging on $P V$ array is neglected.

Equation (4) is for a transmitting system. By interchanging $\tau$ and $p$ the results for $a$ reflecting system are obtained. The parameter, $\Gamma_{B A T}$, compares the electrical storage efficlency to thermal storage efficlency. If electrical energy storage efficlency (nBATnst where nBAT is the efficlency the stored energy is delivered to the load and $n^{\prime}$ t is the efflciency the energy from the PV array is stored) is greater than the thermal energy storage effictency, rst, then $\Gamma_{B A T}>1$. The more likely situation is that nBATnst $<$ nst. As a result $\Gamma_{8 A T}<1$.

Now consider a comparison between the PVHE system and a heat englne oniy system. To obtain the efficiency, $n_{0}$. of the heat engine only system let $f_{\text {pynpy }} \rightarrow 0, \tau \rightarrow T$ and $\rho \rightarrow 0$ in Eq. (4)

$$
n_{0}=\mu n_{C}{ }^{n R E C}{ }^{2} H E
$$

Therefore, from Eqs. (4) and (7) for the case where $\mu$, ${ }_{R E C},{ }^{n} \mathrm{C}$ and ${ }_{n} \mathrm{HE}$ are the same for both the PVHE and heat engine only systems the following is obtained.

$\frac{{ }^{n_{T}}}{{ }^{n_{0}}}=\frac{f_{P V}{ }^{n_{P V}}}{{ }^{n_{R E C}}}\left[\frac{\Gamma_{B A T}}{{ }^{n_{H E}}}-1\right]+\frac{1}{{ }^{n_{H E}}}[1-\tau-\rho]+\tau$

This result applies for a transmitting system, but by interchanging $\tau$ and $\rho$ results for a reflecting system are obtalned.

For an efficlent reflecting system it is required that $t \rightarrow 0$, whereas for an efficient transmitting system $\rho \rightarrow 0$ is desired. For these conditions since $0 \leq \rho \leq 1$ and $0 \leq T \leq 1$ the terms $1 / n R E C(1-r-\rho)+\rho$ for a ref Tecting system and 1/nREC $(1-T-\rho)+T$ for a transmitting system will always be greater than 1. Also, if

$\Gamma_{\mathrm{BAT}} / n_{\mathrm{HE}}>1$, then as Eq. (8) shows, $n_{T} / n_{0}>1$. In Fig. 2, $\eta_{T} / n_{0}$ is plotted as a function of nHE for the case $\Gamma_{B A T}=1$. This result applies to both the transmitting and reflecting systems for $1 / n_{R E C}(1-T-\rho)+\tau=1$ in the transmitting case and $i / \operatorname{nREC}(1-\tau-\rho)+\rho=1$ in the reflecting case. Since these terms are greater than 1 , as discussed above, and for most cases $\Gamma_{B A T} \geq 0.9$ the results in $\mathrm{Fig} .2$ should be representative of 
PVHE systems. It is expected that $0.1 \leq \mathrm{fPV} P \mathrm{PV} / \mathrm{nREC}$ $\leq 0.25$. As a result $n T / n_{0}$ is plotted as a function of HHE for fPVAPV/nREC $=0.1,0.15$. 0.2 , and 0.25 .

From fig. 2 it can be seen that for a heat engine with nHE $\approx 0.2$ the PVHE system shows an improvement in efficlency $1.4 \leq n_{T} / n_{0} \leq 2$ over the heat engthe only system. For ${ }^{H} H E \approx 0.3,1.2 \leq$ $n_{T} / n_{0} \leq 1.6$ and for $n H E \approx 0.4,1.1 \leq n_{T} / n_{0} \leq \overline{1} .4$. Therefore, the PVHE system offers significant improvement in efficlency over a heat engine only system. In the next section an estimate of area and mass savings for the PVHE system will be made.

Concentrator area sautings. The concentrator area savings for the PVHE system compared to a heat engline only system are given by the following result 5 .

$$
\frac{c_{T}}{c_{0}}=\frac{n_{0}}{n_{T}}
$$

Where $C_{T}=A_{C} /\left(P_{E L}+P_{E L}^{\prime \prime}\right)$ is the concentrator specific area in the PVHE system and $C_{0}$ is concentrator specific area in the heat engine only system. Thus the reduction in concentrator specific area is inversely proportional to the efficiency improvement. Figure 3 shows $C_{T} / C_{0}$ as a function of the heat engine efficlency, nHE, for the same conditions as Fig. 2. As can be seen significant reductions in concentrator speciflc area are possible with the PVHE system.

Heat engine radiator area savings. In Ref. 5 the following expression for the ratio of the radiator speciftc area, $r_{T}=A_{R A D} /\left(P_{E L}+P_{E L}\right)$, for for the PVHE system to radiator specific area $r_{0}$, for the heat engine only system is developed.

$$
\frac{r_{T}}{r_{0}}=\frac{n_{0}}{n_{T}}\left[\frac{a}{n_{R E C}}+r\right]
$$

This result is for a transmitting system; replace $T$ by $\rho$ to obtain the result for a reflecting system. In obtaining Eq. (10) it is assumed that both systems operate with the same radlator temperature, emissivity and heat engine efficiency. As wlll be discussed later. In order to have Tov (PV array temperature) as low as possible the absorptivity, $\alpha$, must be small. Therefore, the term in brackets in Eq. (10) wlll be less than one. In that case the reduction in $r / r$ will be greater then the concentrator area reduction, $C_{T} / C_{0}$.

Only the heat engine radiator has been considered above. If the electrical energy storage effictencles (n'st and nBAT) are not large then the radiator area necessary to reject the waste heat from the electrical energy storage system may be significant.

Receiver mass savings. The recelver (including thermal storage material) is one of the most masstve components in a heat engine system. To estimate the recelver mass assume the mass. MREC, is porportional to the input power.

$$
M_{R E C}=B_{R E C} P_{R E C}
$$

where $\beta_{\text {REC }}(\mathrm{kg} / \mathrm{kW})$ is a constant and $P_{R E C}$ is the total recelver power input. Using results from
Ref. 5, the following is obtained for the ratio of PVHE recelver specific mass, $\left(R_{T}=M_{R E C} /\left(P_{E L}+P_{E L}^{\prime \prime}\right)\right.$, to heat engine only recelve specific mass, $R_{0}$.

$$
\frac{R_{T}}{R_{0}}=\left[1-f_{P V}{ }^{n} P V-\rho\right] \frac{n_{0}}{n_{T}}
$$

Equation (12) applies for a transmitting PVHE system; replace $\rho$ by $r$ to obtain the result for a reflecting system. In obtaining Eq. (12) it was assumed that both systems have the same ${ }^{n_{C}}$. $t_{\text {SUN. }} t_{S H}$ and BREC.

In the PVHE system part of the energy storage is done electricaliy. Therefore, to make a valid comparison of recelver mass savings between the PVHE and heat engine only systems the electrical energy storage mass must be included. Assume the electrical energy storage system mass. MBAT. Is. proportional to the amount of stored energy. Est.

$$
M_{B A T}=\frac{E_{S t}^{\prime}}{\alpha_{B A T}}=\frac{t_{S U N} P^{\prime}}{\alpha_{B A T}}
$$

where aBAT ( $\mathrm{kWH} / \mathrm{kg}$ ) is the specific energy density of the electrical energy storage system.

Based on the results of Ref. 5, the following is obtained.

$$
\frac{B_{T}}{R_{0}}=Y_{B A T}{ }^{f} P V^{n_{P V}} \frac{n_{0}}{{ }^{n_{T}}}
$$

Where ${ }^{B} T$ is the electrical storage specific mass, $\left(M_{B A T} /\left(P_{E L}+P_{E L}^{\prime \prime}\right)\right)$, and the parameter. YBAT.

is a measure of electrical energy storage effectiveness. The smaller rBAT 15, the more effective electrical energy storage will be.

$$
Y_{B A T}=\frac{t_{S U N}{ }^{t} S H^{n} s t}{B_{R E C}{ }^{\alpha} B A T\left({ }^{t} S U N^{n} s t^{n} B A T+t_{S H}\right)}
$$

In deriving Eq. (14) it was assumed that $n_{c}$, tsun, and tsH are the same for both the PVHE and heat engine only system. results

If Eqs. (12) and (14) are added the following

$\frac{R_{T}+B_{T}}{R_{0}}=\left[1+f_{P V^{n} P V}\left(Y_{B A T}-1\right)-\rho\right] \frac{{ }^{n_{0}}}{n_{Y}}$

This result applies to a transmitting PVHE system. If $p$ is replaced by $T$ then results for a reflecting PVHE system are obtained. As Eq. (16) shows, the recelver mass savings for the PVHE system are sensitive to the parameters YBAT and $\Gamma_{B A T}$ (determines no/nT. Eq. (8)). Evaluating ГBAT and YBAT requires choosing a specific electrical energy storage system. Consider three battery storage systems as being representative of the state of development of electrical storage systems. First, assume for the the presently avallable nickei-cadmium battery 6 that aBAT $\approx$ $0.004 \mathrm{kWH} / \mathrm{kg}$, nst $\approx 0.8$. nBAT $\approx 0.9$. Second, assume for the soon to be avallable nickel-hydrogen batteryb that $\alpha_{B A T}=0.0139 \mathrm{kWH} / \mathrm{kg}$. nst $\approx 0.8$, nBAT $\approx 0.9$, Findlly, for a future system consider 
the sodium-sulfur battery ${ }^{7}$ wth aBAT $^{2} \approx 0.077 \mathrm{kWH} / \mathrm{kg}$, $n_{\text {' }}^{\prime} \mathrm{t} \approx 0.8$, nBAT $\approx 1$. For the receiver assume $B_{R E C} \approx 6.4 \mathrm{~kg} / \mathrm{kW}$ and $n s t \approx 0.9$, which is representative of the recelver being considered for the Space Station Rankine cycle power system. 8 Therefore, for a system in low earth orb1t with tSUN $\approx$ $1 \mathrm{hr}, \mathrm{t}_{\mathrm{SH}} \approx 38 \mathrm{~min}$. Eqs. (5) and (15) yleld the following results. For NI-Cd: ГBAT $\approx 0.91$, YBAT $\approx 14.6$, for $N 1-H_{2} ; \Gamma_{B A T} \approx 0.91$, YBAT $\approx 4.2$ and finally for $\mathrm{Na}-\mathrm{S} ; \Gamma_{B A T} \approx 0.95$, Y YAT $\approx 0.72$. since $\Gamma_{B A T}>0.9$ for all three systems, the eff 1 clency ratio, no/nT, will be nearly the same for each system. However, the wide varlation in YBAT means there will also be a wide varlation in $\left(R_{T}+\right.$ $\left.B_{T}\right) / R_{0}$. In Fig. $4\left(R_{T}+B_{T}\right) / R_{0}$ is shown as a function of heat engine efficlency for the same cond 1 tions as Flg. 2 with $f_{\text {PUnPV/nREC }}=0.15$ and for three values of the quantity $1+f P V(r B A T-1)-p$ for the transmitting PVHE system or $1+$ fPVnPV (YBAT - 1) - $t$ for the reflecting PVHE system. A value of 3 is representative of $N 1-C d$, a value of 1.5 is representative of $\mathrm{N} 1-\mathrm{H}_{2}$ and a value of 1.0 is representative of $\mathrm{Na}-\mathrm{S}$. As $\mathrm{Fig} .4$ indicates no recelver mass savings will occur if Ni-Cd battertes are used. In the case of $\mathrm{N}_{1}-\mathrm{H}_{2}$ batteries savings will occur for nHE $<0.25$ and for Na-S batterles savings occur for all nHE. A large mass addttion wlll result if a PVHE system must use $\mathrm{NI-Cd}$ batterles. This large mass penalty makes a PVHE system using Ni-Cd batterles unattractive for a low earth orbit power system.

\section{Photovoltalc Array Temperature Regutrements}

As already mentioned, the major problem for the PVHE systems is the requirement for high temperature operation of the PV array. The PV array temperature. Tpv, must be greater than the bottom temperature of the heat engine radiator. $T_{B}$, in order for the PV array to reject its waste heat $\left(a n^{p} p_{n}\right)$ to the heat engine working fluid.

To estimate. TPv. a simple heat transfer analysis presented in Ref. 5 was carried out. The assumptions made in that analysis are the following.

1. PV array temperature, $T_{P V}$, is constant

2. heat transfer coefficlent, $h$, is constant

3. specific heat, $C_{p}$, of working fiuld flowing over pv array is constant

\section{4. radiation from PV array neglected}

Using these assumptions the following result was obtained for $\mathrm{Ku} \gg \mathrm{I}$.

$$
\Delta T=T_{P V}-T_{B}=\alpha K
$$

Therefore, in order to minimize aT the absorptivity must be low.

The parameter, $K$, is determined by the PV array optical properties the ratto of shade time to sun time, $t_{S H} / t_{S U N}$, and a characteristic temperature for the heat engine. This characteristic temperature is $\Delta H / C_{D}$. where $\Delta H$ is the enthalpy change of the working fluid across the recelver in a heat engine only system and $C_{p}$ is the specific heat of the working flutd at the
PV array. The parameter, $U$, is determined by the ratio of total PV array area to concentrator area, $A_{T} / A_{C}$, and the heat transfer coefficlent $h$. Thus $u$ can be varied by changing the location of the $P V$ array with respect to the concentrator (varying $A_{T} / A_{C}$ ).

$$
\begin{aligned}
& u=a\left(\frac{A_{T}}{A_{C}}\right) \frac{n}{{ }_{{ }_{c}} p_{S U N}} \\
& a=\frac{A_{T}}{A_{h}} \\
& K=\frac{1+\frac{t_{S H}}{t_{S U N}{ }^{n} S t}}{a+\tau n_{R E C}} \frac{\Delta H}{C_{D}}
\end{aligned}
$$

The ratto of $P V$ array area, AT, to the heat transfer area. Ah, is given by the parameter, a. since, the heat transfer area wlll be equal on less than total array area. a $\leq 1$. The expression for $K$ given by $E q .(20)$ is for a transmitting PVHE system. For a reflecting system merely replace $T$ by $p$ in Eq. (20).

Consider values for $K$ that are representative of heat engines being studied for the space Station. Two of these are the tolvene Rankine 8 heat engine $\left(\Delta H / C_{p} \approx 280 \mathrm{~K}\right)$ and the $H E$ - $X_{e}$ Brayton 8 heat engfne $\left(\Delta H / C_{p} \approx 180 \mathrm{~K}\right)$. Also, assume a low earth orbit $\left(t_{S H} / t_{S U N} n_{S t}=2 / 3\right)$ and $\alpha+$ inREC $=0.7$ for a transmitting system or $a+$ PAREC $=0.7$ for a reflecting system. For the Brayton cycle under these condtions $K \approx 430 K$ and for the Rankine cycle $K \approx 670 \mathrm{~K}$. If $\alpha<0.3$ then, according to Eq. (17), the temperature rise, $\Delta T<200 \mathrm{~K}$, should be attalnable. For $\alpha>0.3$. however, temperature rises greater than $200 \mathrm{~K}$ wlll result. In this case the temperature of the $P V$ array, Tpy, may be too high for PV conversion. For the toluene Rankine heat engine 8 the bottom temperature of the cycle is $T_{B} \approx 340 \mathrm{~K}$. The He - Xe Brayton heat engine system 8 has a bottom temperature $\approx 290 \mathrm{~K}$. However, the working fluld enters the compressor rather than the heat source at this temperature. Therefore, heat addition occurs after the compressor. At this point the temperature $B$ is $T_{B} \approx 380 \mathrm{~K}$. Therefore, for $\Delta T \approx 200 \mathrm{~K}$ the $P V$ array temperature would be $T_{P V} \approx 540$ to $580 \mathrm{~K}$. Operation of gallium arsentue (GaAs) PV cells at temperatures $>600 \mathrm{~K}$ are discussed in Ref. 1. The efficlency npv. decreases with increasing temperature. I.9 However, the decrease in efficiency can be partialiy balanced by operating at high intensity, as in the proposed PVHE systems. Effictency increases with intensity 1.9 up to about 1000 PSUN. Two possible candidates for a high temperature, high intensity PV cell are the vertical multijunction (VMJ) cel110-12 and the interdigitated back contact PV cell consldered for thermophotovoltalc conversion. 13,14

Besides low absorptivity, a reduced value of the parameter, $K$, wlll also result in lower array temperature, Tpu. A posstble method for reducing is to reduce $\Delta H$. This can be done by increasing the mass flow rate in the heat engine cycle. How ever. such a change wlll also alter the heat engine 
cycle performance. In the design of a PVHE system it will be necessary to vary the heat engine operating conditions in order to find the optimum.

COMPARISON OF SPACE STATION ORGANIC RANKINE CYCLE AND PVHE

Earlier it was shown how the PVHE system can result in significant reductions in mass and area compared to a heat engine only system. Now consider a mass and area comparison between the toluene Rankine cycle (ORC) being consldered for the Space station 8 and a PVHE system that uses the same Rankine cycle. The Space Station system consists of two modules that each produce $25 \mathrm{kWe}$ Table I lists the ORC performance parameters for a 25 k'we module taken from Ref. 8, as we?! as, the assumed values used for the PVHE system. The assumed PVHE system is etther reflecting ( $\rho=0.5$, $T=0.05, a=0.3)$ or transmitting $(\rho=0.05$, $T=0.05, \alpha=0.3$ ). Using Eq. (B) and the parameters in Table 1 , the efficlency ratio is the following.

$$
\frac{n_{T}}{n_{0}}=1.39
$$

The overall efficlency of the ORC system is 0.17 , which includes the power conditioning efficiency and the electrical power for the concentrator controls. Assuming these losses are the same for the PVHE system then the effictency of the PVHE system is the following.

$$
n_{T}=0.17(1.39)=0.23
$$

Table II presents the results of the mass and area comparison. The concentrator and radiator areas for the PVHE system were calculated using Eqs. (9) and (10). The PVHE concentrator and radiator masses were obtalned by assuming they are proportional to their respectlve areas. Recelver and battery mass for the PVHE system were calculated using Eqs. (12) and (14). Two battery masses are shown in Table II; one based on blpolar nickel-hydrogen batterles 6 (aBAT $\approx 0.139 \mathrm{kWh} / \mathrm{kg}$ ) and the other on sodlum sulfur batteries 7

$\left(a_{\text {BAT }} \approx 0.077 \mathrm{kWH} / \mathrm{kg}\right)$. The mass of the Rankine power conversion unit for the PVHE system was obtained by assuming the mass is a linear function of power output. Interface structure mass.

(including the gimbel joint for the concentrator,) for the PVHE system was obtalned using the same fraction of the total mass as for the Rankine only system (structure mass/total mass $=0.15$ ). Mass of the PV array in the PVHE system was calculated assuming the same specific mass as that of the concentrator $\left(6.6 \mathrm{~kg} / \mathrm{m}^{2}\right)$ and a concentrator to a PV array area ratio of $A_{C} / A_{P V}=50$. A radiator is necessary to reject the waste heat of the electrical storage system. An estimate of the mass and area of this radiator was obtained by assuming the waste heat was rejected at a temperature of $30{ }^{\circ} \mathrm{C}$ and emissivity of 0.9 with the same mass/area as the heat engine radiator. Not included in Table II is the mass of the power condtitioning equipment.

Severd interesting results are pointed out by Table [I. Flrst of all the total PUHE system mass for aBAT $=0.0139 \mathrm{kWH} / \mathrm{kg}$ is nearly 25 percent less than the ORC system. The PVHE concentrator area is 30 percent less than the ORC system concentration area. Also, the PVHE radiator area is
40 percent less than the ORC system radiator area. The major mass and area savings for the PVHE system occur for the radlator. Finally. since batterles are not a major portion of the total mas5. using the optimistic sodium-sulfur batteries rather than nickel-hydrogen batterles does not result in a major reduction in the total mass of a PVHE system. For an all PV array power system the batterles are the major mass component. Therefore, in that case a large energy density electrical storage component is critical for obtaining a low mass sytem. Whereas, the PVHE system mass is much less sensitive to the electrical storage mass.

The large radiator mass and area savings of the PVHE system result because the waste heat of the PV array (PREJ in Fig. 1) is used by the heat engine rather than rejected to space. Only by operating the PV array at high temperature is it possible to utflize the PV array waste heat in the heat engine cycle. If the PV array can not operate at high temperature then $P R E J$ would have to be rejeted to space. This low temperature heat rejection would require a large radlator area.

Consider an estimate of the PV array temperature, Tpv, required in the above example. Assuming $\mathrm{Ku} \gg 1$, then $\mathrm{Eq}$. (17) can be used to estimate Tpy. From the data in Table I. $K=646 \mathrm{~K}$. Therefore, using Eq. (17) and a bottom temperature ${ }^{8}$. $T_{B}=60 \mathrm{C}$. the following is obtained. $T_{P V}=527 \mathrm{~K}$. Reaching $P V$ array temperatures this high is the critical issue for the space PVHE system. Without high temperature PV array operation the large area and mass savings are not posstble.

\section{Concluston}

Both transmitting and reflecting PVHE systems result in significant efficlency improvements, over a heat engine only system $\left(1.1 \leq n_{T} / n_{0} \leq 2\right)$. choosing between the reflecting and transmitting systems depends on several things. One important consideration is the PV array absorptivity, $\alpha$. In order to maintain the PV array temperature. TPV. as low as posstble a must be small $(\alpha<0.3)$. Also, for the transmitting system the reflectivity, $\rho$. must be small. Whereas for the reflecting system the transmittance, $\tau$, must be small. Research on reflecting and transmitting PV arrays is necessary to determine which can best meet these requirements. However, the critical issue for both PV array types is that operation at high temperature $\left(T_{P V} \approx 600 \mathrm{~K}\right.$ ) is required. A sultable PV cell structure that wlll meet the high temperature requirements is the essential ingredient for a successfui PVHE system.

As a result of improved efficlency over a heat engine $\left(n_{T} / n_{0}>1\right)$ the PVHE systems will have corresponding savings in concentrator area $\left(C_{T} / C_{0}=n_{0} / n_{T}\right)$. Also, the PVHE system will result in heat engine radiator savings greater than concentrator area savings. Recelver and energy storage mass savings will occur for the PVHE system if high energy density electrical storage (YBAT < 1) is avallable. A mass penalty will occur if low energy density electrical storage. such as nickelcadmium battertes are used.

A mass and area comparison was made between the Space Station organic Rankine cycle power system and a hypothetical PVHE system using the same Rankine system. Nearly a 25 percent reduction in 
overall mass was calculated, as well as a concentrator area reduction of 30 percent and a radiator area savings of 40 percent for the PVHE system.

Besides efflclency, area and mass savings the PVHE systems have a degree of inherent system redundacy. If the PV array should fall without blocking the input solar flux the heat engine part of the system would stlli be able to provide part of the electrical load. Simllarly, if the heat engine should fall without interrupting the flow of the system fluld the PV array would be able to produce part of the electrical load.

\section{References}

1. Stirn, R.J., "An Overview of Novel Photovoltaic Conversion Techniques at High Intensity Levels. "Radtation Energy Converston in Space, K.W. Billman, ed., AIAA, New York. 1978, pp. 136-151.

2. Jurisson, J., "Multicolor Solar Cell Power System for Space," Radiation Energy Converston in Space. K.W. 811 iman, ed., AIAA, New York. 1978, pp. 152-158.

3. Ratajczak, A.R., "Theoretical Performance of Solar-Cell Space Power Systems Using Spectral olspersion. I - Dispersion by Prism Reflector," NASA TN $0-4156,1967$.

4. Klucher, T.M., "Theoretical Performance of Solar-Cell Space Power Systems Using Spectral olsperston. II - Oispersion by Diffraction Grating." NASA TN D-4157, 1967.

5. Chubb, D.L.. "Combination Solar Photovoltaic Heat Englne Energy Converter," Journal of Propulston and Power, Vol. 3, No. 4, JulyAug. 1987, to be published.

6. Manzo, M.A. and Hoberecht, M.A., "A $37.5 \mathrm{kw}$ Point Design Comparison of the Nickei-Cadmium Battery, Blpolar Nickel-hydrogen Battery, and Regenerative Hyorogen-Oxygen Fuel Cell Energy Storage Subsystems for Low Earth orbit." Advanced Energy Systems - Their Role in Our Future (19th IECEC), Vol. 1, American Nuclear Soclety, La Grange Park, IL, 1984, pp, 287-294.
7. Wise, J.F., "Comparison of High Power Solar Power System Concepts to Other Options," Elghteenth IEEE Photovoltaic Specialists Conference. IEEE New York, 1985, pp. 418-423.

8. "Space Station WP-04 Power System, Preliminary Analys is and Design Document OR-02," Vol. 1 , RI/R085-320-2, Rocketdyne Division, Rockweli Internationa 1, Canoga Park, CA, Dec. 1986.

9. Hovel, H.J., Semiconductors and Semimeta 7s, Vol. 11 - Solar Cells, Academic Press, New York, 1975, D. 173.

10. Sater, B.L., Brandhorst, H.W. Jr., Riley, T.J., and Hart, R.E. Jr., "The Multiple Junction Edge Illuminated Solar Cell," I0th IEEE Photovoltalc Speclallsts Conference. IEEE, New York, 1973, pp. 188-193.

11. Sater, B.L. and Goradia, C., "The High Intensity Solar Cell - Key to Low Cost Photovoltalc Power," 11th IEFE Photovoltalc Specialists Conference. IEEE, New York, 1975, pp. 356-363.

12. Goradla, C. and Sater, B.L.. "A First Theory of the $p^{+}-n-n^{+}$Edge-Illuminated S1licon Solar Cell at Very High Injection Leveis," IEEE Transactions on Electron Devices, Vol. 24, No. 4, Apr. 1977, pp. 342-351.

13. Swanson, R.M., "Recent Developments in Thermophotovoltaic Conversion," IEEE International Electron Devices Meeting. IEEE, New York, 1980, DD. 186-189.

14. Swanson, R.M. and Bracewe 11, R.N., "Stlicon Photovoltalc Cells in TPV Conversion," EPRI-ER-633, Electrlc Power Research Institute, Palo Alto, CA, Feb. 1978. 
TABLE I. - PERFORMANCE PARAMETERS OF SPACE STATION

25 kWe ORGANIC (TOLUENE) RANKINE CYCLE (ORC)

POWER SYSTEM AND HYPOTHETICAL PVHE SYSTEM

USING THE SAME ORC

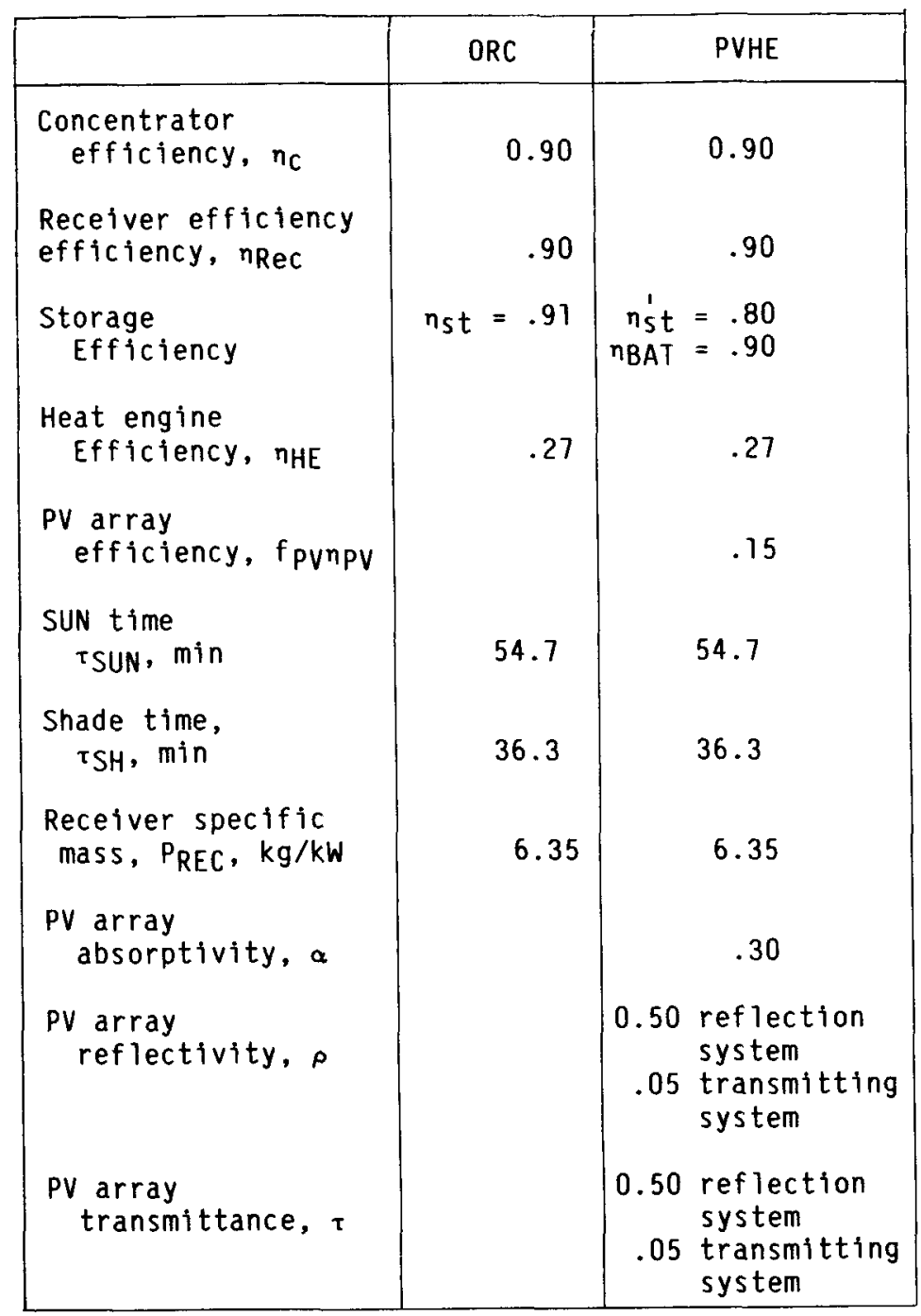


TABLE II. - COMPARISON OF SPACE STATION ORC POWER SYSTEM AND HYPOTHETICAL PVHE SYSTEM USING THE SAME ORC

[Electrical Power Output $=25 \mathrm{kWe}$ ]

\begin{tabular}{|c|c|c|c|c|}
\hline Component & $\begin{array}{l}\text { Mass for } \\
\mathrm{ORC}, \mathrm{kg}\end{array}$ & Mass for PVHE, kg & $\begin{array}{l}\text { Area for } \\
\text { ORC, } \mathrm{m}^{2}\end{array}$ & $\begin{array}{l}\text { Area for } \\
\text { PVHE, } \mathrm{m}^{2}\end{array}$ \\
\hline Concentrator & 1414 & 1018 & 213 & 153 \\
\hline $\begin{array}{l}\text { Receiver and } \\
\text { thermal storage }\end{array}$ & 1426 & 821 & & \\
\hline Electrical storage & & $\begin{array}{l}610\left(\alpha_{B A T}=0.0139 \mathrm{kWH} / \mathrm{kg}\right) \\
110\left(\alpha_{B A T}=0.077 \mathrm{kWH} / \mathrm{kg}\right)\end{array}$ & & \\
\hline Heat engine & 567 & 340 & & \\
\hline PV array & & 20 & & \\
\hline Heat engine radiator & 2182 & 1309 & 160 & 96 \\
\hline $\begin{array}{l}\text { Electrical storage } \\
\text { radiator }\end{array}$ & & 199 & & 15 \\
\hline $\begin{array}{l}\text { Interface structure } \\
\text { and Beta Gimbel joint }\end{array}$ & 982 & $\begin{array}{l}756\left(\alpha_{\text {BAT }}=0.0139 \mathrm{kWH} / \mathrm{kg}\right) \\
668\left(\alpha_{\text {BAT }}=0.077 \mathrm{kWH} / \mathrm{kg}\right)\end{array}$ & & \\
\hline Total & 6571 & $\begin{array}{l}5073\left(\alpha_{\text {BAT }}=0.0139 \mathrm{kWH} / \mathrm{kg}\right) \\
4485\left(\alpha_{\text {BAT }}=0.077 \mathrm{kWH} / \mathrm{kg}\right)\end{array}$ & 373 & 261 \\
\hline
\end{tabular}

ORC efficiency, $\eta_{0}=0.17$

PVHE efficiency, $n T=0.23$;

ORC specific mass $=263 \mathrm{~kg} / \mathrm{kWe}$

PVHE specific mass $=203 \mathrm{~kg} / \mathrm{kWe}\left(\alpha_{B A T}=0.0139 \mathrm{kWH} / \mathrm{kg}\right)$

PVHE specific mass $=179 \mathrm{~kg} / \mathrm{kWe}\left(\alpha_{B A T}=0.077 \mathrm{kWH} / \mathrm{kg}\right)$

$\begin{aligned} & \text { Power ratio for } \\ & \text { PVHE system }\end{aligned}=\frac{\text { Power output of } O R C}{\text { Power output of PV array }}=\frac{P_{E L}}{P_{E L}^{\prime}}=0.78$ 


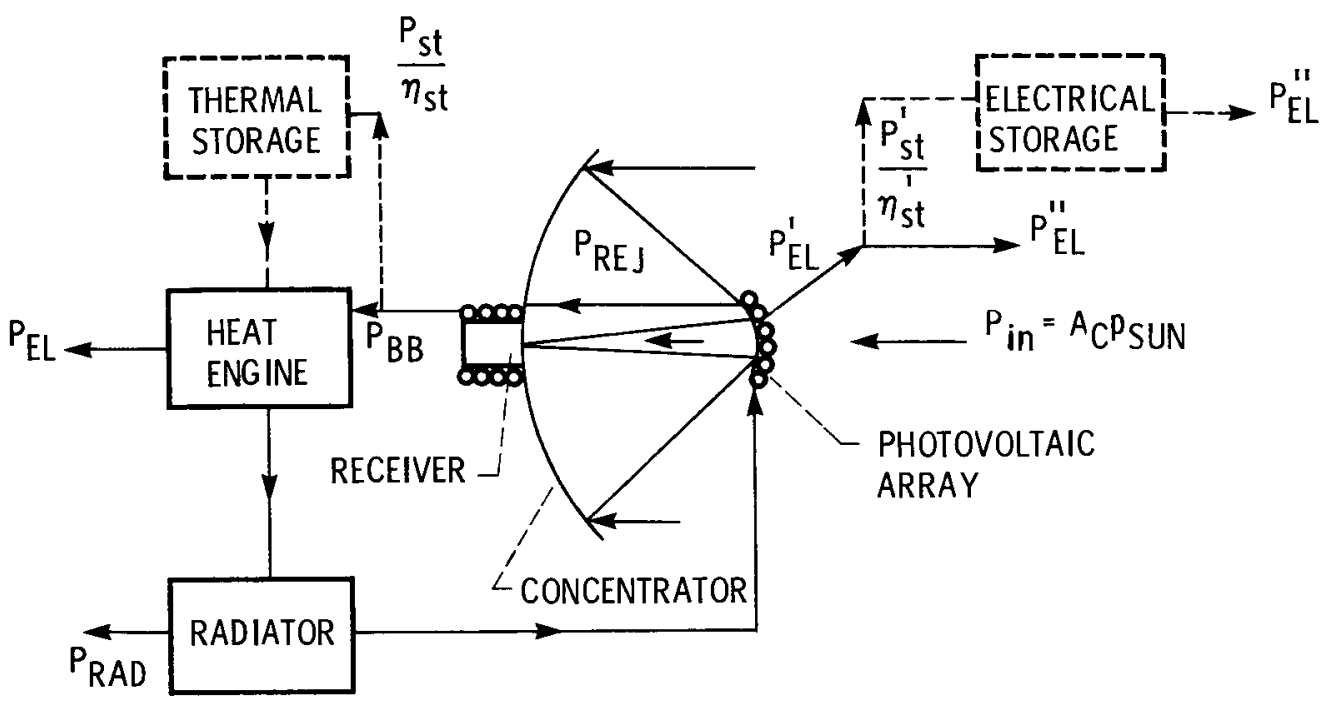

(a) Reflecting system.

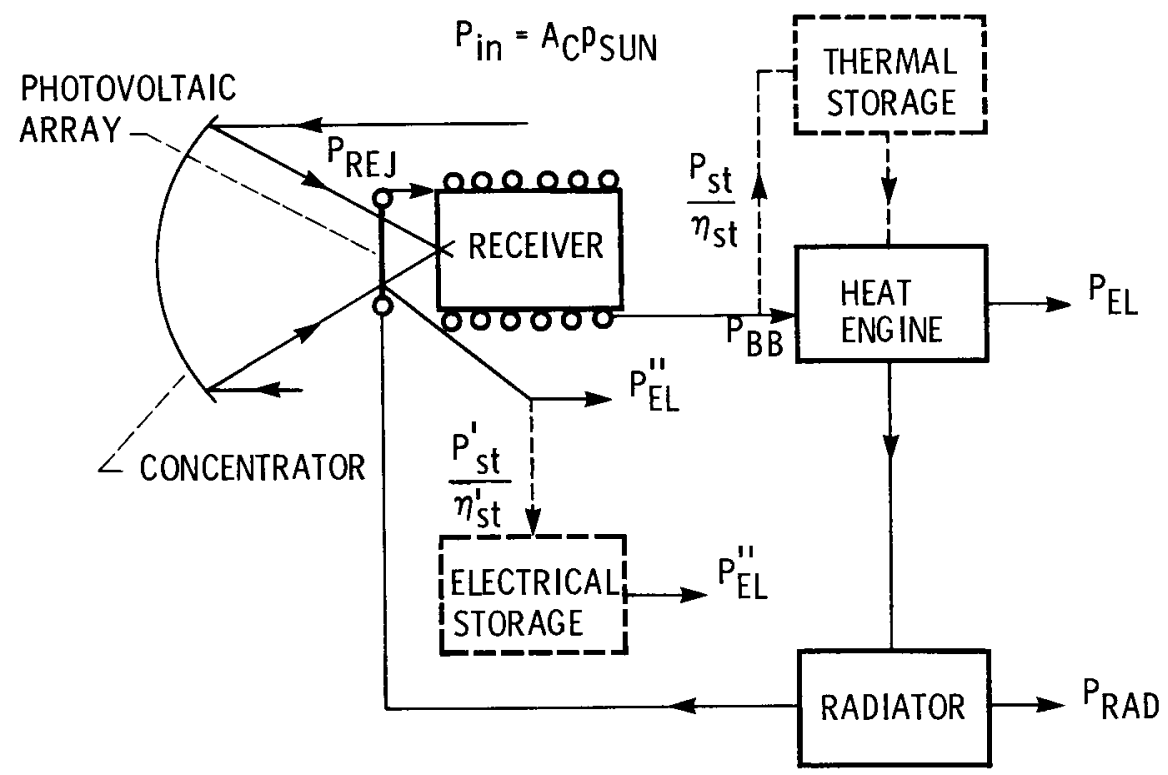

(b) Transmitting system.

FiguRE 1. - SCHEMATIC DIAGRAMS OF PHOTOVOLTAIC hEAT ENGINE (PVHE) SYSTEMS. 


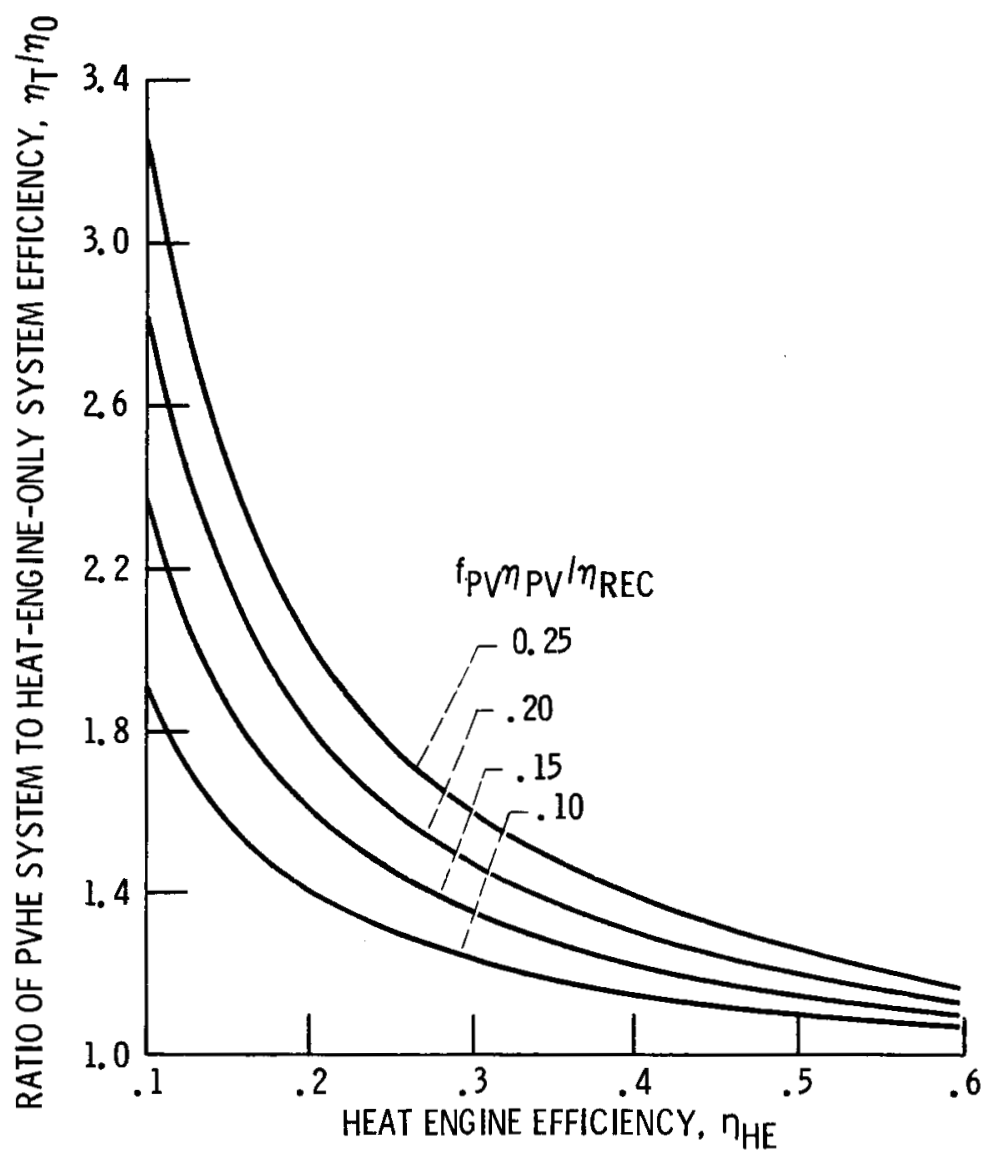

FIGURE 2. - EFFICIENCY IMPROVEMENT FOR PVHE SYSTEM OVER HEAT ENGINE WITH BOTH SYSTEMS OPERATING WITH SAME CONCENTRATOR EFFICIENCY $\eta_{C}$ AND RECEIVER EFFICIENCY $n_{\text {REC }}$. ALSO, FOR REFLECTING PVHE SYSTEM $1 / \eta_{R E C}(1-\tau-\rho)+\rho=1$. AND FOR TRANSMITTING PVHE SYSTEM, $1 / \eta_{\text {REC }}(1-\tau-p)+\tau=1$. FOR COMBINATION ELECTRICAL AND THERMAL ENERGY STORAGE $\Gamma_{\text {BAT }}=1$. 


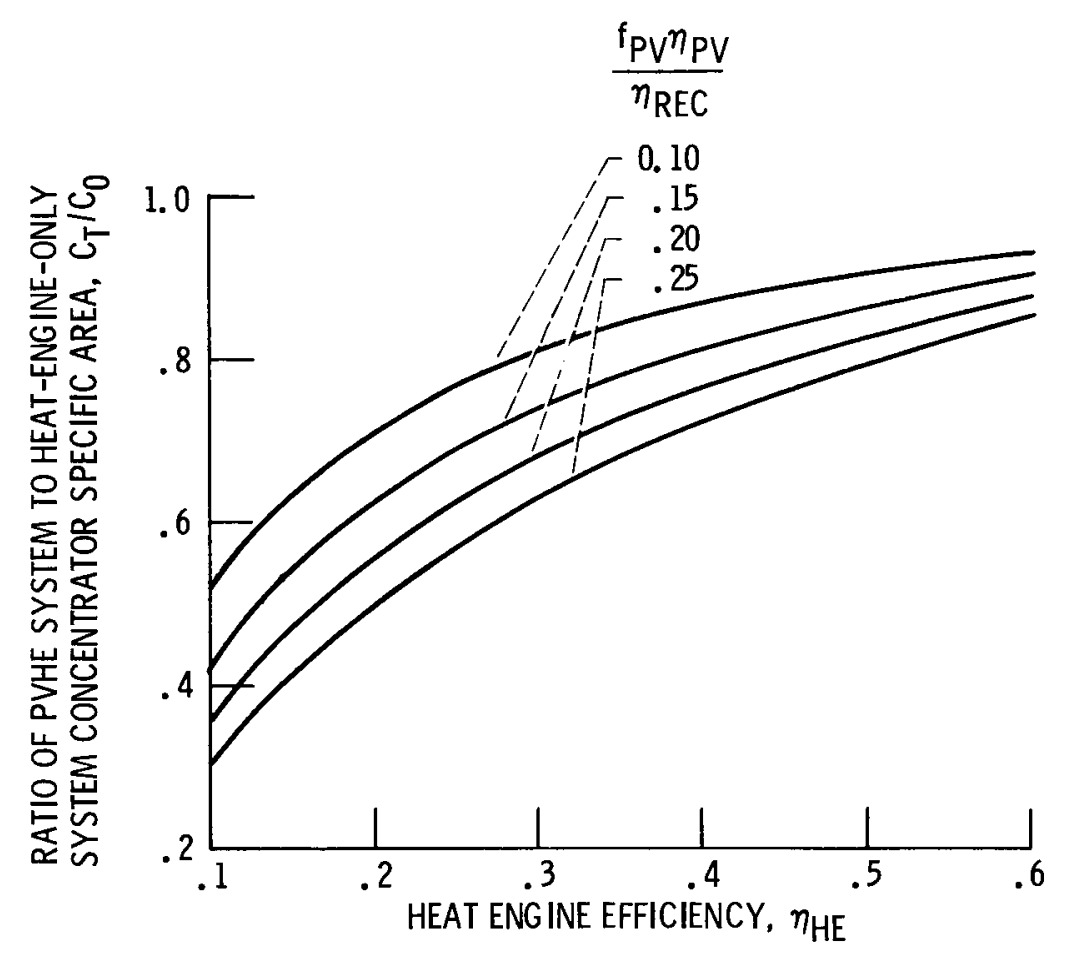

FIGURE 3. - CONCENTRATOR AREA SAVINGS FOR PVHE SYSTEM OVER HEAT ENGINE WITH SAME CONDITIONS AS FIG. 2. 


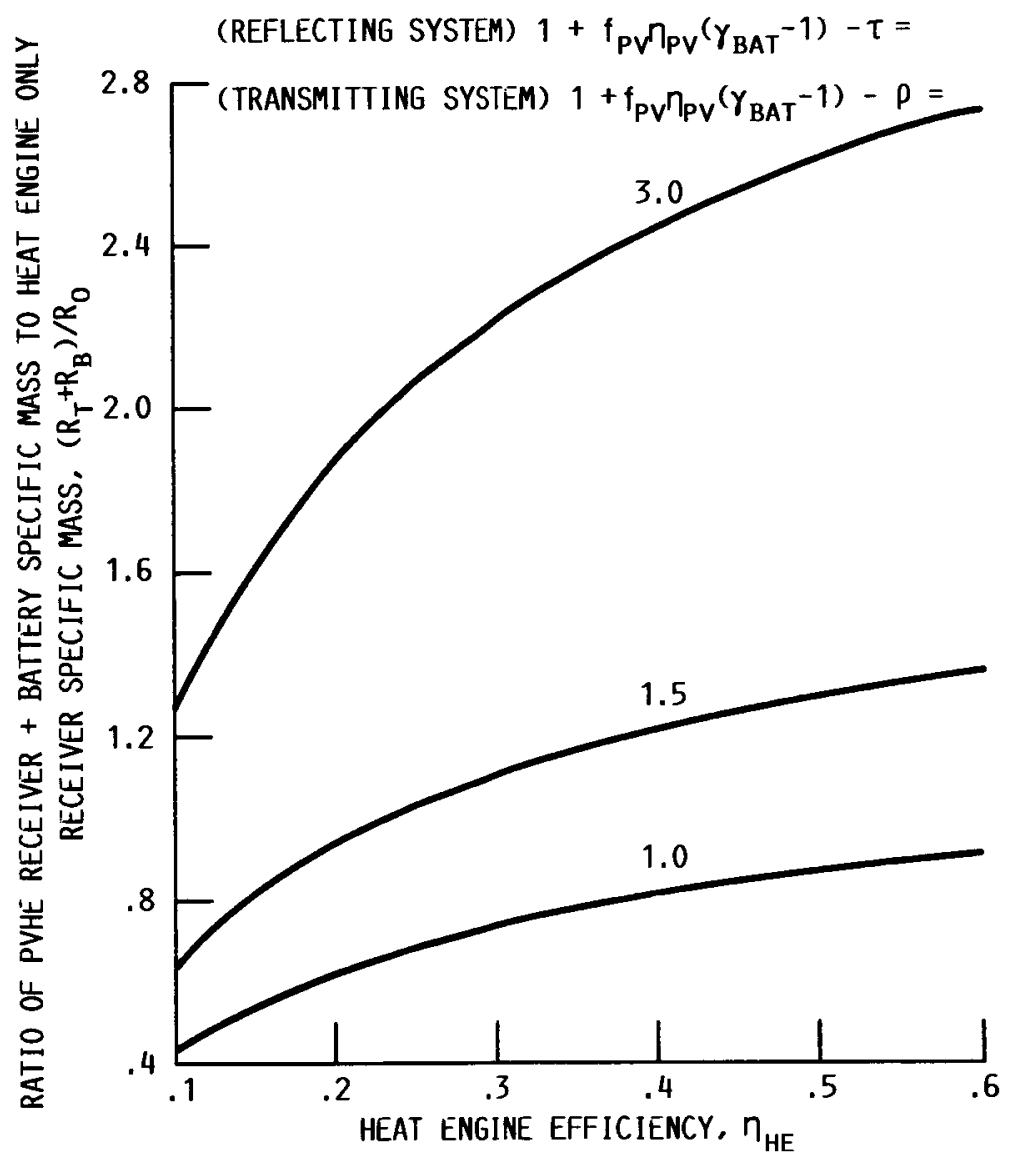

FIGURE 4. - RECEIVER MASS SAVINGS FOR PVHE SYSTEM OVER HEAT ENGINE ONLY SYSTEM WITH SAME CONDITIONS AS FIG. 2. IN ADDITION, $f_{\mathrm{PV}} \eta_{\mathrm{PV}} / \eta_{\mathrm{REC}}=.15$. 


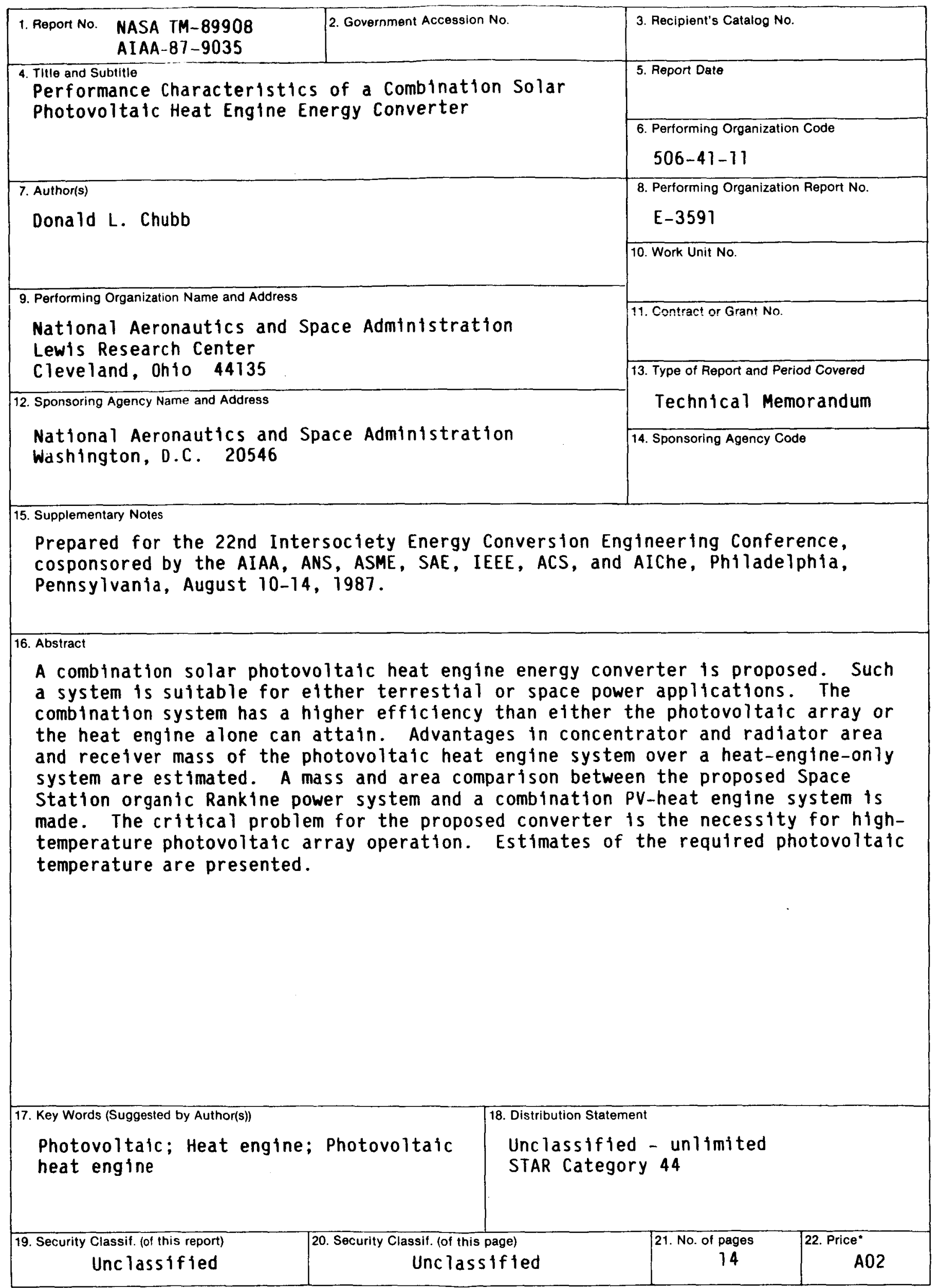

*For sale by the National Technical Information Service, Springfield, Virginia 22161 